\title{
Impact of tax competition on fiscal incomes of Kazakhstan in terms of tax competitive environment
}

\author{
Aliya Shakbutova ${ }^{1, *}$, Abdizhapar Saparbayev ${ }^{2}$, Popek Stanislaw ${ }^{3}$ Aiymzhan Makulova ${ }^{4}$, \\ Aigerim Nurmukhan ${ }^{1}$ \\ ${ }^{1}$ Al-Farabi Kazakh National University, al-Farabi Ave. 71, 050040 Almaty, Kazakhstan \\ ${ }^{2}$ National Academy of Sciences of the Kazakhstan, Shevchenko St., 28, 050000 Almaty, Kazakhstan \\ ${ }^{3}$ Cracow University of Economics, Rakowicka St., 27, 31-510 Cracow, Poland \\ ${ }^{4}$ University Narxoz, Zhandosov St., 55, 050035 Almaty, Kazakhstan
}

\begin{abstract}
International tax competition requires tax reforms from all countries in the world. To meet international standards, countries use different methods to attract resources to their economies. Fierce tax competition in the world has prompted Kazakhstan to significantly liberalize the tax system, reduce the number of taxes and their rates for the main types of taxes, and simplify tax registration procedures, tax accounting and tax reporting for taxpayers, making it one of the most attractive tax systems in the world. However, such actions and reforms aimed at improving tax competitiveness may in one way or another affect Kazakhstan's fiscal income, which is an important topic of research. The research is based on the tax system and tax income of the Republic of Kazakhstan in the international tax competitive environment. In the course of the study, the tax system of Kazakhstan, its features and reforms, and the structure of the budget income of Kazakhstan were primarily analyzed. Keywords: tax competition, tax system, fiscal income, effects of tax competition.
\end{abstract}

\section{Inroduction}

Many countries compete with each other at the international level for leadership in the production and sales of an expanded assortment of goods and services outside their own countries. As the mobility of goods, services and factors of production has increased in recent years, countries have begun to compete for the possibility of attracting foreign investment and capital to their countries. In order to be competitive and increase the attractiveness of their tax systems and tax regimes in the modern market system, countries are undertaking many targeted tax reforms. A country's tax attractiveness for legal entities and business people is part of its national competitive advantages, and economic agents ' willingness to register as tax-residents of a given state also depends on the essence of the government's tax policy.

${ }^{*}$ Corresponding author: ashakbutova@mail.ru 


\section{Literature Review}

Taxes are an important factor that affects the economic condition of a country, company and the public. In this regard, Adam Smith wrote, "The owner of capital ... is a citizen of the world, who will leave the host country in the event of tax problems, and transfer his capital to where he will enjoy it without additional loss" [1].

In accordance with the situations of recent years, it can be noted that the influence of the tax policy of economic developed countries has increased and in this connection, the adverse effects for other countries are growing, such as the outflow of labor and capital, the growth of the shadow economy, and so on. this proves that simplification of tax policy and reduction of tax burden are not the only factors for tax competition.

Tax competition arises when the state chooses a strategy to attract direct or indirect foreign investment (cash): foreign investment and the high cost of human resources due to minimization of taxation and / or the provision of special tax benefits allow to make the country competitive [2]. Tax competition, which is expressed in a reduction in taxes, can negatively affect the planning of the national budget, social services by reducing state incomes. On the other hand, this deficit can be compensated by attracting foreign capital to the jurisdiction, which allows not only to significantly reduce the unemployment rate in the country, but also to stimulate the flow of money and the activities of institutions.

In 1996, G7 countries turned to the OECD to clarify and legitimize the rules of fair competition, and after that the topic of tax competition became relevant. In 1996, G7 countries turned to the OECD to clarify and legitimize the rules of fair competition, and after that the topic of tax competition became relevant. In this regard, the first report of the European Commissions and the OECD became the basis for the study of economics, law and international relations $[3,4]$.

Of these treatments are the following basic features of tax competition:

1) competition in the tax system is associated with tax reforms and government actions that differ from other countries and attract foreign taxpayers.;

2) tax rivalry is always a conflict between the requirements of the tax structures, some of which are more important to the needs of taxpayers and more desirable;

3 ) the subjects of competition are people and their associations, leading the fight for competitive objects [5]. The main subjects of tax rivalry are different levels of state power, while others are taxpayers: persons and legal entities.;

4) the objects of competition are real world phenomena for which there is a competition [6]. The target of the rivalry is tax capital which can be transferred to another contry's territory;

5) Tax competitiveness aims at obtaining the full amount of tax money by amending the national tax legislation.

The intensity of international tax competitiveness is becoming more aware of and the chance of harming one another by trying to create each country's tax system more appealing than other countries. Tax competition is described as "interactive tax setting by independent governments in a non-cooperative, strategic way" [7]. Fiscal interdependence is necessary if tax competition is to occur. In other words, one jurisdiction's fiscal policy (i.e. nation, municipality) impacts the other jurisdictions' tax base. Due to its mobility, capital is the primary aim of fiscal competition.

\section{Methodology of the research}

In the context of the spread of tax processes, countries pay more attention to improving the tax system and determining the directions of the tax policy of the country, which is a key 
indicator of tax competition. With the improvement of the mobility of labor and capital resources, another type of competition has emerged at the international level, which manifests itself in the form of competition of tax institutions and represents the competition of countries for obtaining these resources. Its impact on international financial flows and the redistribution of labor and capital is as significant as ambiguous. With the emergence of unfair competition and the ambiguous consequences of this situation, there was a need to limit tax competition and streamline some aspects and general approaches to the formation of tax policy. The aim of the article is to identify the changes in the tax system and fiscal income of Kazakhstan in a tax competitive environment.

In the methodology, information from secondary sources was analyzed. Secondary information is based on a desk study of literature, which covers the main theoretical aspects related to concept of tax competition; Kazakhstan tax system and effects of tax competition; statistical data on the dynamics of tax incomes and the structure of tax incomes, the dynamics of the GDP of Kazakhstan; statistics of Kazakhstan; Paying Taxes report; World Bank statistics and OECD statistics; European statistics and additional resources that may contribute to the study of international tax competition.

The research is based on the tax system and tax income of the Republic of Kazakhstan in the international tax competitive environment.

\section{Results and discussion}

Kazakhstan takes meaningful measures to increase the competitiveness of the tax system in order to attract additional foreign investment, international capital, and generally organized business to the Kazakhstan economy. Moreover, if earlier the state's aspirations were mainly aimed at overcoming internal problems in taxation, now Kazakhstan has radically revised its views on its place in the global tax system and has significantly changed the direction of its foreign tax policy.

Comparing the structure of the tax burden in Kazakhstan and other countries, it should be noted that the income tax rate in advanced economies is approximately $30-40 \%$ (in Kazakhstan - 20\%); personal income tax - from 30 to 60\% (in Kazakhstan - 10\%); social tax from employers - from 8 to 40\% (in Kazakhstan - 9.5\%); VAT - 10-20\% (in Kazakhstan $12 \%$ ).

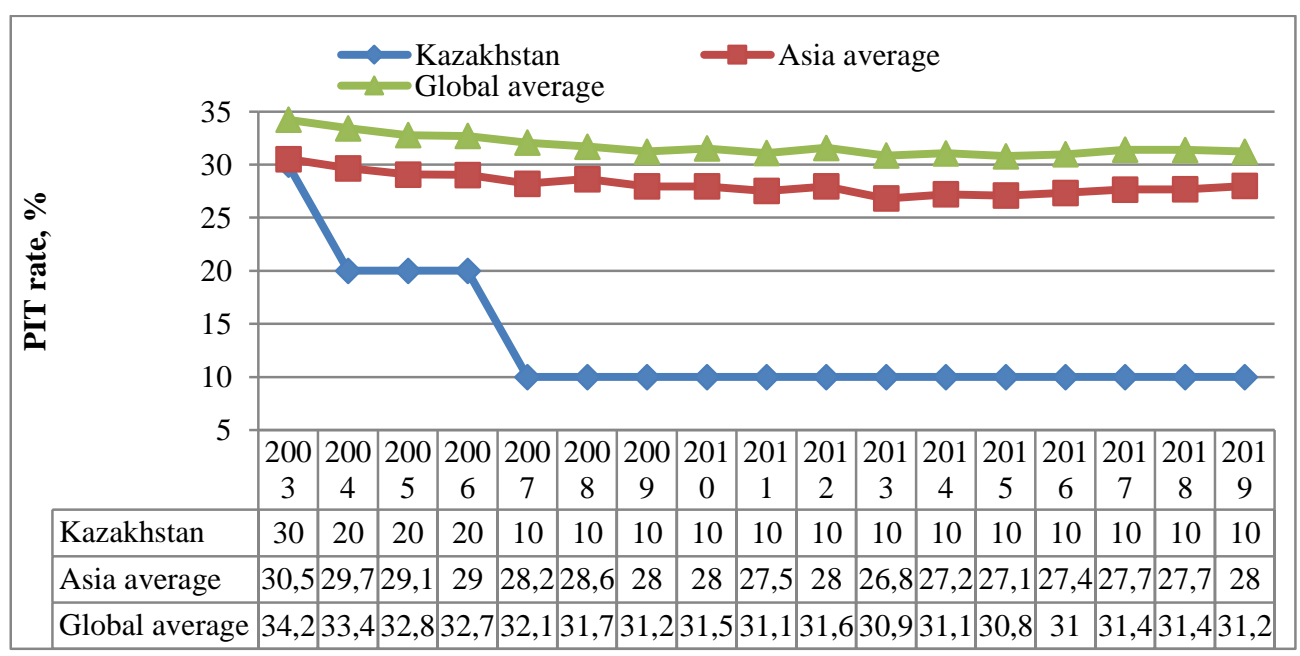

Fig. 1. Dynamics of personal income tax rates of Kazakhstan. 
Comparing the tax rates of PIT in Kazakhstan, the average rate of PIT in Asia and the average rate of PIT in the world, the tax rate of PIT in Kazakhstan is lower from percentage point since 2004, and from 17-22 percentage point since 2007. But in 2003, the rate of PIT in Kazakhstan was relatively equal to average PIT in Asia [8].

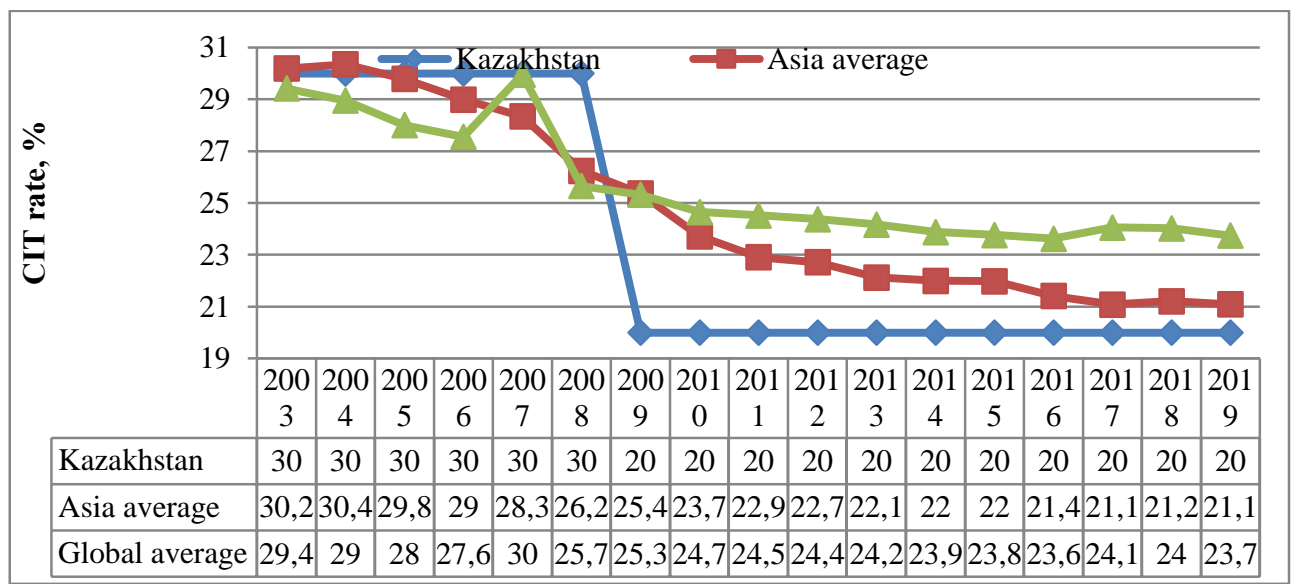

Fig. 2. Dynamics of corporate income tax rates of Kazakhstan.

Comparing the CIT rate of Kazakhstan and the average CIT rate in Asia, in 2003-2004 the Kazakhstan CIT rate was lower than the average CIT rate in Asia. In subsequent years (2005-2008), the average CIT rate decreased in Asia, and the CIT rate in Kazakhstan was higher. Since 2009, the CIT rate of Kazakhstan has been lower than the average CIT rate in Asia. During the periods of 2003-2019, the corporate income tax rate of Kazakhstan changed once in 2009 , from $30 \%$ to $20 \%$. Until 2007, the tax rate was higher than the global average tax rate. In 2007, the average global CIT rate was almost equal to Kazakhstan's CIT rate. Since 2009, the CIT rate of Kazakhstan has been significantly lower than the average global CIT rate [9]. Considering these changes it can be assumed that in recent years, the tax rate CIT in Kazakhstan in the world and in Asia more attractive.

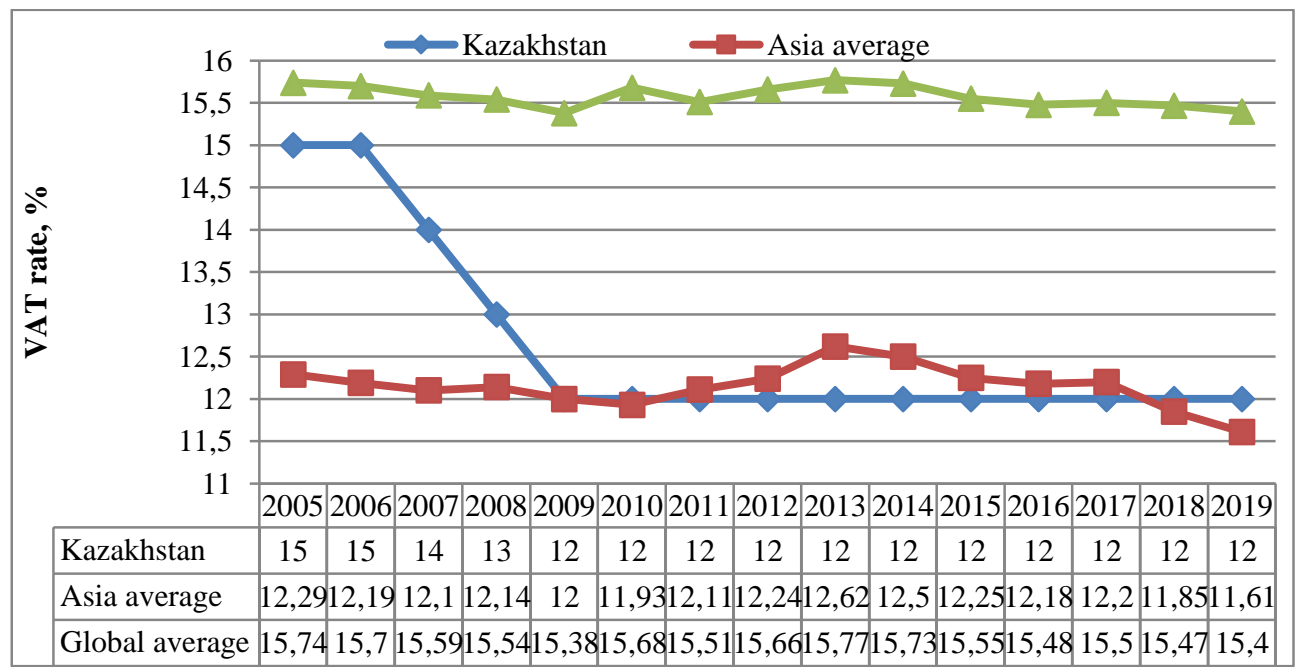

Fig. 3. Dynamics of value added tax rates of Kazakhstan. 
In accordance with the presented Figure 3, it can be noted that the tax rate of VAT in Kazakhstan has always been low, taking into account the fact that Kazakhstan only since 2007 began to reduce VAT rates.

From 2005 to 2008, Kazakhstan's VAT rate was higher than the average VAT rate in Asia. In 2009 and 2010, these rates were almost comparable. Since 2011 the average rate in Asia has increased and since 2018 began to fall. As a result, in the periods of 2011-2017, the VAT rate of Kazakhstan is lower than the average VAT rate in Asia, and higher in 20182019. This means that at present, the attractiveness of Kazakhstan's VAT in the world is higher than among Asian countries [10].

To analyze the attractiveness of the tax system in Kazakhstan, indicators were analyzed according to Paying Taxes report.

Table 1. Kazakhstan's position on Paying Taxes Report 2019.

\begin{tabular}{|c|c|c|c|c|}
\hline $\begin{array}{c}\text { Overall ranking / } \\
190\end{array}$ & $\begin{array}{c}\text { Total Tax \& } \\
\text { Contribution Rate (\%) }\end{array}$ & $\begin{array}{c}\text { Time to comply } \\
\text { (hours) }\end{array}$ & $\begin{array}{c}\text { Number of } \\
\text { payments }\end{array}$ & $\begin{array}{c}\text { Post-filing } \\
\text { index }\end{array}$ \\
\hline 56 & 29.4 & 182 & 7 & 48.9 \\
\hline
\end{tabular}

In the Paying Taxes Report 2019 by PwC and the World Bank Group, Kazakhstan ranks 56th out of 190 countries. This report examines the balance between labor and income taxes, as economies take into account the impact of changes in the nature of work and the impact that this has on income streams. According to this report, the total tax and contribution rate in Kazakhstan is $29.4 \%$. The total tax and contribution rate measures the amount of taxes and mandatory contributions that a business incurs in its second year of operation, and is expressed as a share of its commercial profit. Time to comply taxes in Kazakhstan is 182 hours. And in this report shown number of payment and post-filling index respectively: 7 and $48,9[10]$.

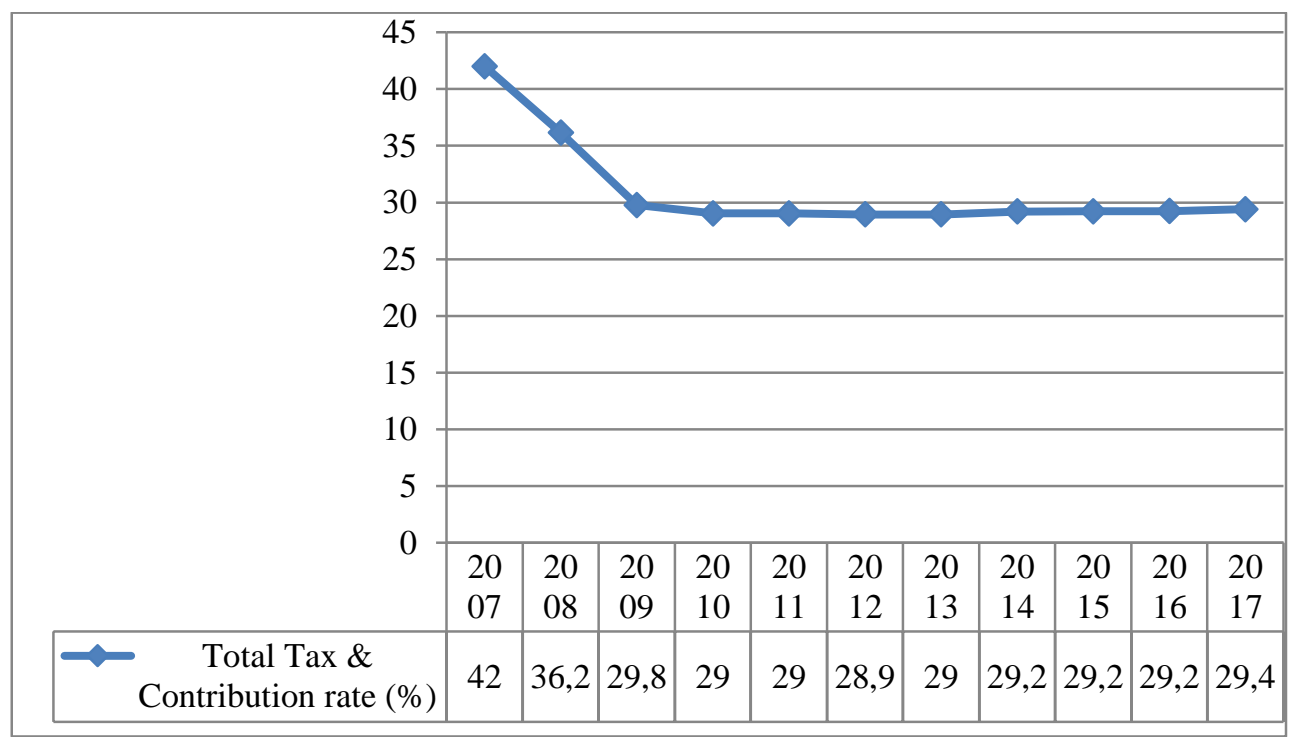

Fig. 4. Dynamics of total tax and contribution rate of Kazakhstan in Paying Tax Repot.

Total tax and contribution rate in the period 2007 - 2009 fell sharply from $42 \%$ to $29.77 \%$. From 2010 to 2014 it gradually decreased to $29.21 \%$. From 2015 to 2017 , it rose slightly to $29.4 \%$. 


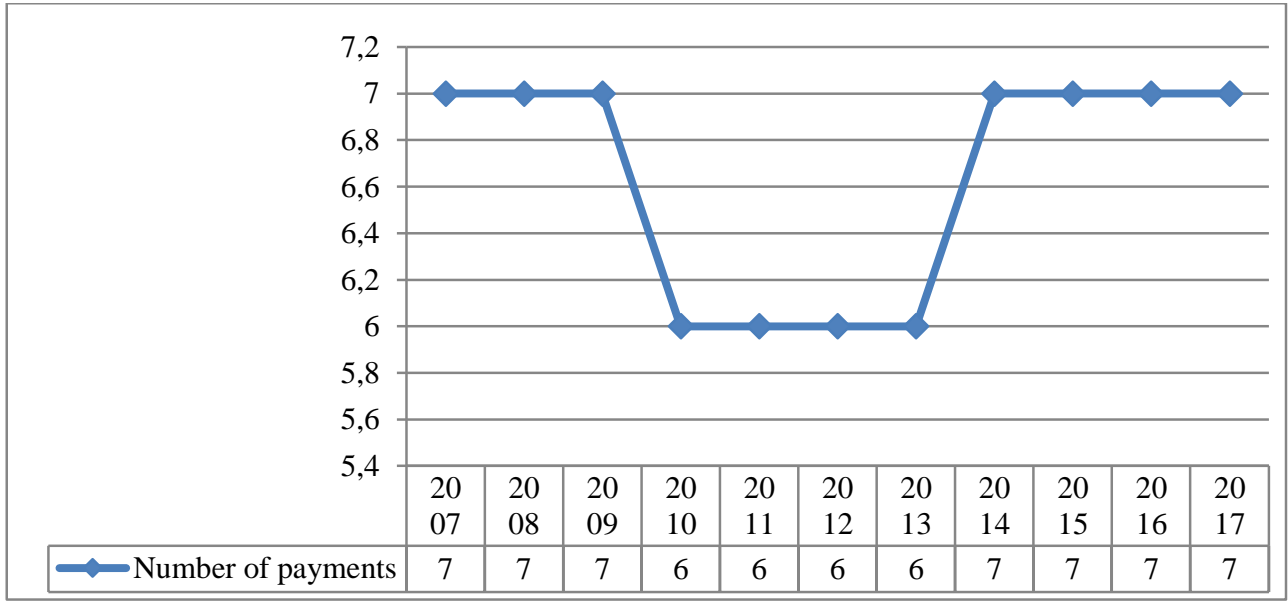

Fig. 5. Dynamics of number of payments of Kazakhstan in Paying Tax Repot.

Number of payments for the first 3 years $(2007,2008,2009)$ was 7 . Since 2010 the next 4 years was 6 . The last 4 years $(2014,2015,2016,2017)$ again rose to 7.

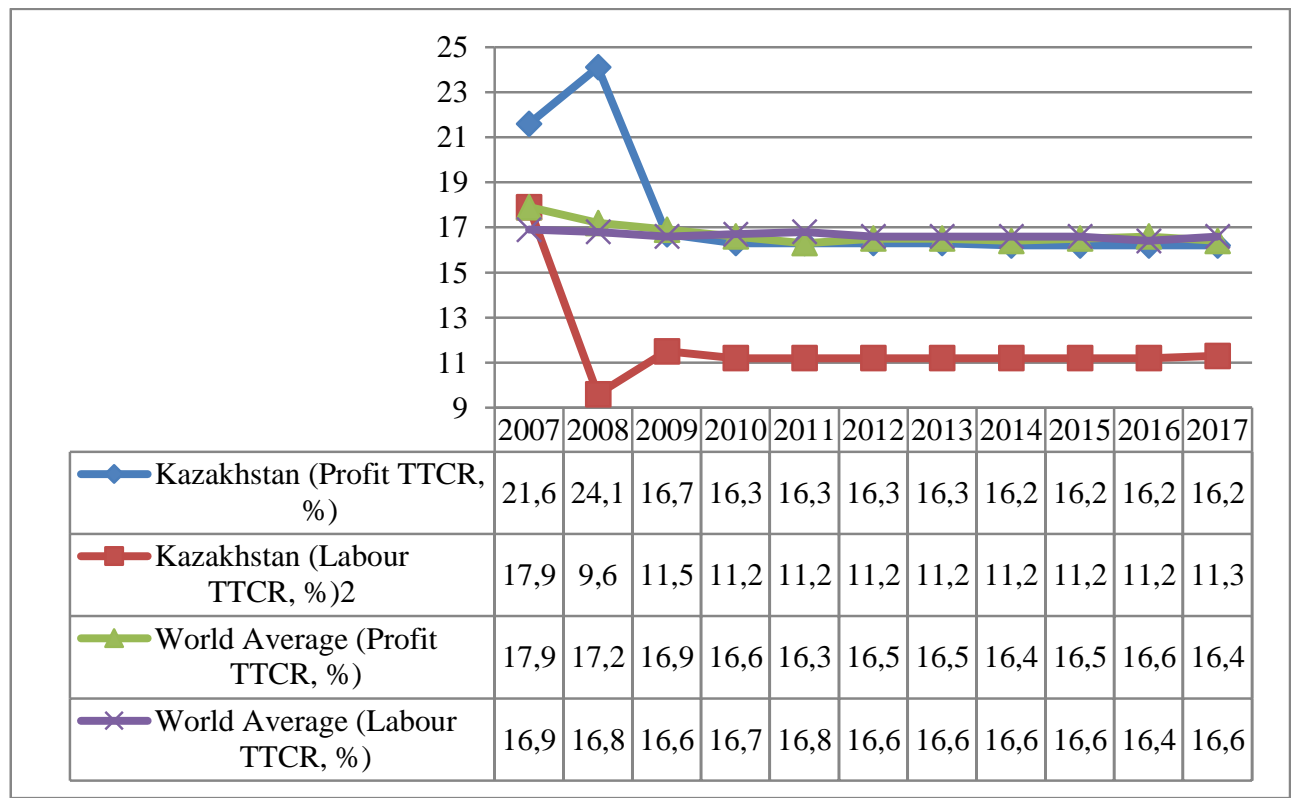

Fig. 6. Dynamics Of Profit and Labour Total Tax And Contribution Rate Of Kazakhstan.

In comparison with the profit TTCR of World average, the 2007 profit TTCR of Kazakhstan was $3.7 \%$ higher. In 2008, there was a difference of $6.9 \%$ between profit TTCR of Kazakhstan and the profit TTCR of World average. But since 2009, their levels are approximately the same (a difference of $0.3-0.2 \%$ ).

In 2007, labour TTCR of Kazakhstan was slightly higher than labour TTCR of World average. The biggest difference between labour TTCR of World average and labour TTCR of Kazakhstan was 7.2\% in 2008. From 2009 to 2017, their difference is relatively stable $(5.1-5.4 \%)$. 


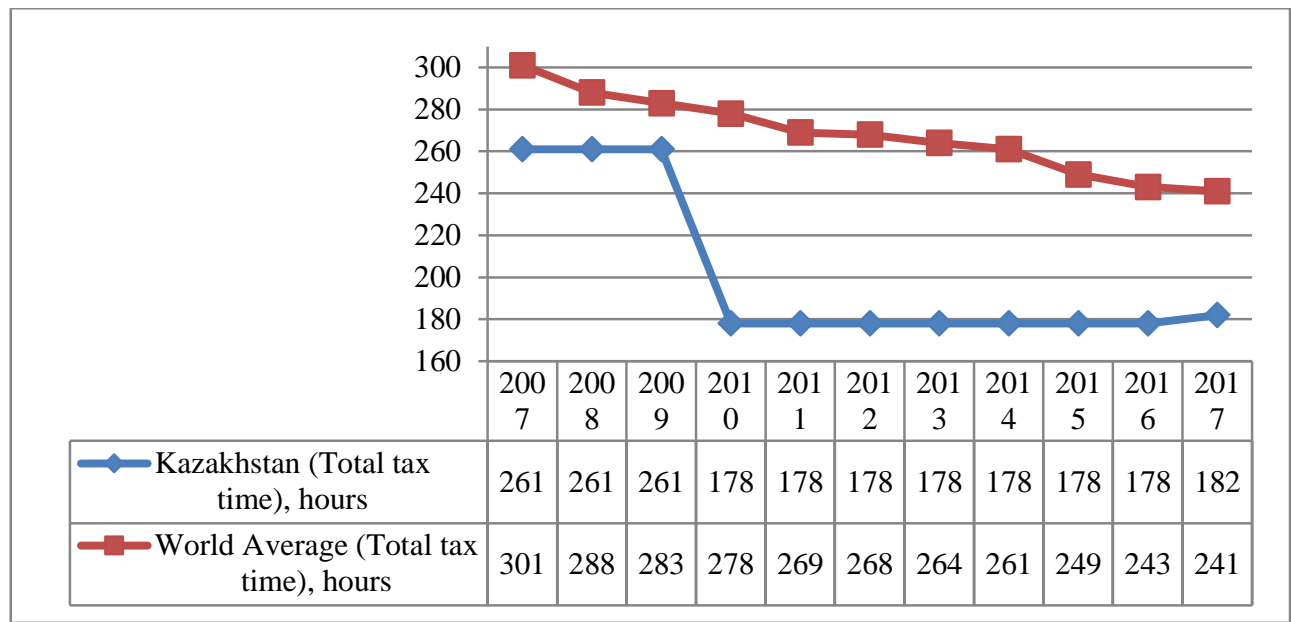

Fig. 7. Dynamics of Time to Comply of Taxes.

Due to the fact that in the period 2007-2009, total tax time of world average gradually decreased and total tax time of Kazakhstan were the same, their difference was 22-50 hours. Since 2010, their difference was 65-100 hours.

To assess the economic growth rate of Kazakhstan, the country's competitiveness is considered. The World Economic Forum defines national competitiveness as the ability of a country and its institutions to ensure stable economic growth rates that are sustainable in the medium term [11].

Table 2. Global Competitiveness Index 2018.

\begin{tabular}{|c|l|c|}
\hline Rank / 140 & \multicolumn{1}{|c|}{ Country } & Score: $0-100$ \\
\hline 1 & United States & 85.6 \\
\hline 2 & Singapore & 83.5 \\
\hline 3 & Germany & 82.8 \\
\hline 4 & Switzerland & 82.6 \\
\hline 5 & Japan & 82.5 \\
\hline 6 & Netherlands & 82.4 \\
\hline 7 & Hong Kong SAR & 82.3 \\
\hline 8 & United Kingdom & 82.0 \\
\hline 9 & Sweden & 81.7 \\
\hline 10 & Denmark & 80.6 \\
\hline 59 & Kazakhstan & 61.8 \\
\hline 140 & Chad & 35.5 \\
\hline
\end{tabular}

According to the report, it was revealed that Kazakhstan ranks 59 out of 140 . This means that the country's competitiveness is above average.

Of course, today in Kazakhstan one of the lowest tax rates in the world. Compared with the closest and even distant neighbors - this is a clear competitive advantage. But imperfect and repressive legislation on liability for tax offenses, cumbersome tax control procedures, the lack of values and active citizenship of judges and tax authorities in tax enforcement often neutralize the good intentions of our legislator. In addition, the risks of inadequate application by Kazakhstani tax authorities and courts of the very progressive tax law and international tax treaties themselves also deter foreign investors and international capital from entering the 
economy of Kazakhstan. And these negative phenomena in our legal reality should be recognized as obvious competitive shortcomings of Kazakhstan.

As a positive point, it should be pointed out that with the adoption of the new Tax Code of the Republic of Kazakhstan, tax authorities have finally recognized that the implementation of international tax treaty norms can be carried out by all parties to tax legal relations directly without their administration by the efforts and individual law enforcement acts of the tax authorities [12].

Thus, in the tax legislation of the Republic of Kazakhstan, the constitutional principle of the direct application of international treaties was implemented. By virtue of the direct constitutional provision, international treaties ratified by the republic are valid before its laws and are applied directly.

Another factor complicating the analysis of the dynamics of tax incomes (in general and of certain types of taxes) is inflation. It is determined by the growth of tax incomes. There are several ways to eliminate the effect of inflation [13]:

- adjust tax income data to the consumer price index;

- use tax incomes as a percentage of GDP;

- recalculate tax incomes in hard currency.

The simplest of the above methods of accounting for inflationary processes is to use the indicator of tax intensity of GDP, i.e. tax incomes as a percentage of GDP.

Gross Domestic Product (GDP) is the main, most comprehensive official indicator of public welfare. It gives an idea of the general material welfare of the nation, since the higher the level of production, the higher the welfare of the country.

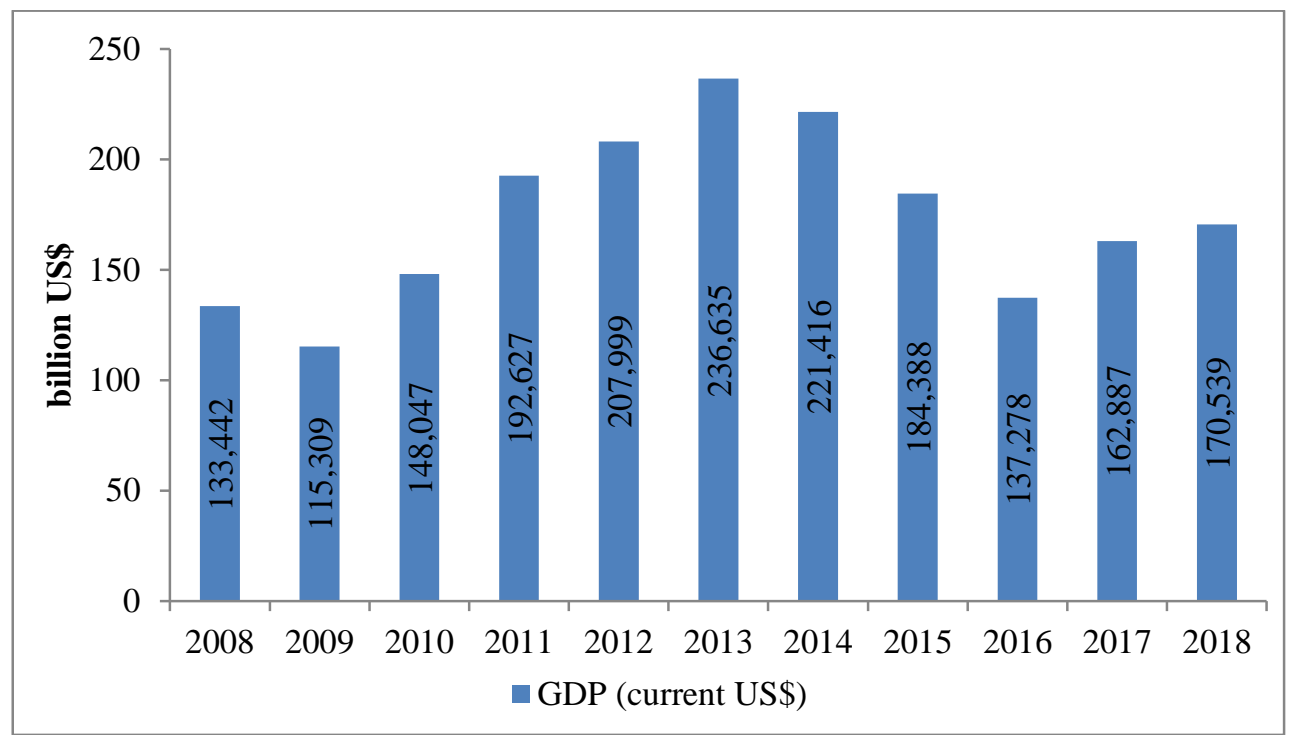

Fig. 8. Level of GDP of Kazakhstan.

From 2009 to 2013, Kazakhstan's GDP gradually increased and reached 236.635 billion US dollars. Then 2014 to 2016 decreased and GDP in 2016 was 137.278 billion US dollars. GDP in 2017 compared to 2016 increased by $15.7 \%$ and in 2018, compared with the previous year, the size of GDP increased by $4.49 \%$ [14].

GDP is a measure of the output being produced, measuring the value of the final goods and services being produced. This ensures that GDP does not include the prices of intermediate goods and services used in the manufacturing process (such as raw materials, 
materials, fuel. Energy, seeds, feed, freight transport services, wholesale, commercial and financial services, etc.).

The authorities deliberately employ government spending and taxes to control the economic situation. By controlling them the state can control aggregate demand and GDP to achieve the expected values for the national economy's growth. While contemplating government spending, it should be remembered that they increase the value of total market spending and promote aggregate demand growth, and subsequently, GDP increase. The aggregate demand will increase by the amount of government expenditure as a result of the public procurement. In comparison, a decline in government spending means a drop in total spending and a reduction in GDP. Accordingly, government spending directly affects national development and employment [15].

Remember now the effect of aggregate taxes on demand-another part of fiscal policy. An increase in taxes contributes to a reduction in real net profits, and therefore to a decline in consumer spending, which will influence total expenditure. If the amount of expenditure and government spending is the same then a reduction in consumer spending would result in a decline in GDP and employment [16].

High taxes slash labor, development, expenditure, and savings opportunities, thus limiting economic growth. It is often noted that the difficulty of preparing accounting and tax statements, the scope and uncertainty of the law, the complicated accrual and payment-related processes, as well as tax refunds, can be equated to an additional tax burden. [16].

The results of the analysis of the tax burden on Kazakhstan's economy should be presented as a share of tax revenues in the value of GDP.

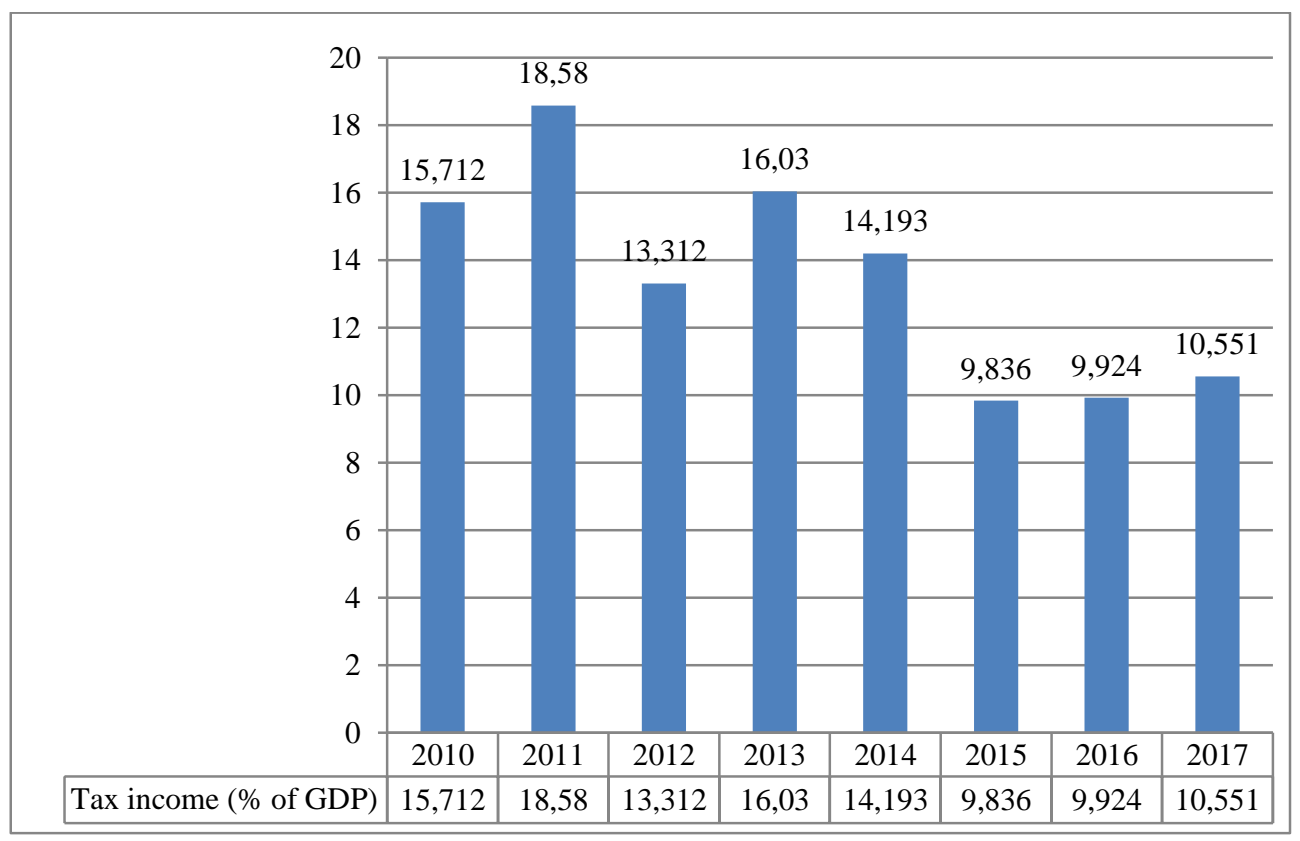

Fig. 9. Level of tax income (\% of GDP) of Kazakhstan.

In the period 2010-2017, the highest share of Kazakhstan's tax income in GDP was in 2011 and amounts to $18.58 \%$. In addition, the lowest share of tax income in GDP was in 2015 and amounted to $9,836 \%$. The share of tax income during this period fell twice in 2012 and 2015. Over the course of two years, the tax share gradually increased and in 2017 amounted to $10.55 \%$. 


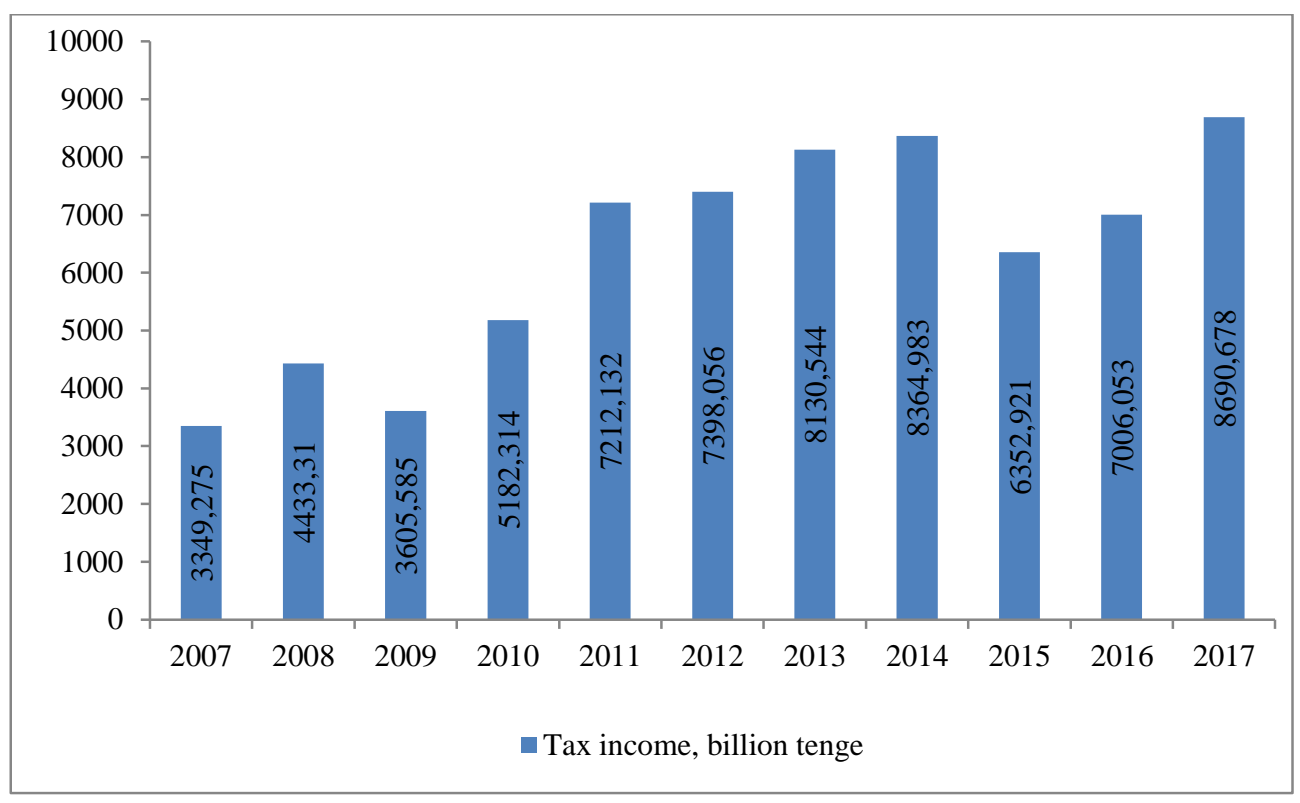

Fig. 10. Dynamics of tax income of Kazakhstan.

From 2007 to 2017, the lowest tax income of Kazakhstan was in 2007 and amounted to 3349,275 billion tenge. Since 2009, tax income increased to 2014 and amounted to 8364.983 billion tenge. In 2015 compared with the previous year tax income decreased by $31.67 \%$. In addition, in 2017, compared with 2016, the tax income of Kazakhstan increased by 19,38\% and amounted to 8690.678 billion tenge [17].

The role of taxes in the formation of state budget incomes is determined by the specific gravity indicators [18]:

- tax incomes in the total amount of budget incomes;

- a separate group of taxes (for example, direct or indirect) in the total amount of budget incomes; incomes;

- a specific tax (for example, corporate income tax) in the total amount of budget

- a separate group of taxes in the total amount of tax incomes;

- specific tax in the total amount of tax income.

These indicators with varying degrees of detail characterize the importance of taxes in the formation of state budget incomes in general and tax incomes in particular. It is through tax incomes that the state manages to satisfy the various needs of its citizens. The share of tax incomes in the central budgets of developed countries is $80-90 \%$.

Taxes perform two main functions - fiscal and regulatory. It is the functions performed that make it possible to determine the role of taxes in the economy and their place in society. The fiscal function of taxes determines the main purpose of taxes, since taxes in modern conditions are the main way to attract income to the state budget, the basis of its welfare.

Considering the concept of the budget, it must be said that the budget is central to the financial system of any state; it is the state's financial plan (listing income and expenses) for the current (financial) year. Of great importance for the formation of a budget at any level are government incomes. Incomes represent a part of the national income of a country that is circulated through various types of cash receipts into state ownership in order to create a financial base for the implementation of tasks and functions. 


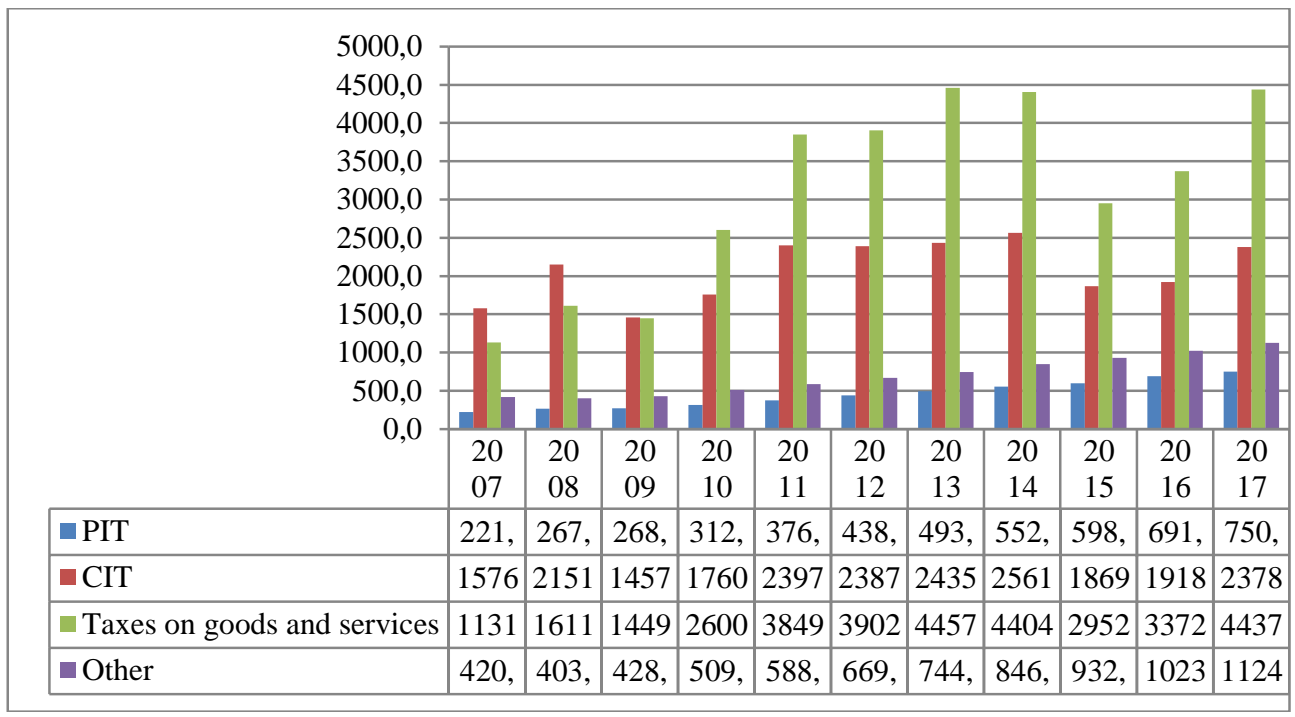

Fig. 11. Structure of tax income of Kazakhstan (billion tenge).

As can be seen from the figure, the largest tax income was from 2007 to 2009 from the corporate income tax. In 2010, income of taxes on goods and services exceeded income from CIT. Income from CIT in 2009 decreased by 47.6\%; in 2012 decreased by $0,43 \%$; in 2015 decreased by $37 \%$. But in the last two years, income from CIT has increased in 2016 by $2.6 \%$; in 2017 by $23.9 \%$. Personal income tax income and income of other taxes increased gradually year after year.

Table 3. Changes of tax income of Kazakhstan 2008-2017.

\begin{tabular}{|l|l|l|l|l|l|l|l|l|l|l|}
\hline & 2008 & 2009 & 2010 & 2011 & 2012 & 2013 & 2014 & 2015 & 2016 & 2017 \\
\hline $\begin{array}{l}\text { Changes, } \\
\%\end{array}$ & 24,45 & $-22,96$ & 30,43 & 28,15 & 2,5 & 9 & 2,8 & - & 9,3 & 19,38 \\
\hline Changes & $\uparrow$ & $\downarrow$ & $\uparrow$ & $\uparrow$ & $\uparrow$ & $\uparrow$ & $\uparrow$ & $\downarrow$ & $\uparrow$ & $\uparrow$ \\
\hline
\end{tabular}

Subsequently, tax competition and significant tax reforms Kazakhstan's tax income in 2017 increased by 19, $38 \%$. The study revealed that the tax income of Kazakhstan over the past 3 years has increased. However, in 2009 and 2015 there was a decline in tax income.

From this it follows that tax income in the periods 2007-2017 mainly increased (8 out of 10). Only 2 years there was a decrease in tax income. The reason for the first decline in tax income was a reduction in tax rates. The Code of the Republic of Kazakhstan "On taxes and other obligatory payments to the budget" established from 01.01.2009 a reduction in rates: value added tax from 13 percent to 12 percent; social tax from 13 percent (the upper level of the regressive taxation scale) to 11 percent a single rate was introduced regardless of the level of income; corporate income tax from 30 percent to 20 percent.

Since 2014, the global economy has seen a slowdown in growth rates and, as a consequence, a decrease in world commodity prices, which significantly affects tax income $(-31,67 \%$ in 2015). 


\section{Conclusion}

International tax competition requires tax reforms from all countries of the world. In order to meet international standards, countries use various methods of attracting resources into their economies.

To be competitive in the environment of tax competition, Kazakhstan has had a series of reforms. As a result, tax rates were reduced, tax benefits, zero rates, etc. were added. The study found that the tax reforms in Kazakhstan affected tax income.

The study was based on Kazakhstan's tax income for the years 2007-2017. During the analysis of factors related to tax competition that affect the tax revenue of the budget of Kazakhstan, the following conclusions can be made:

- firstly, the attractiveness of the tax system of Kazakhstan for other potential taxpayers is medium;

- $\quad$ secondly, as in many countries, the main share of budget revenues is generated using tax revenues;

- thirdly, recently in the structure of tax revenue, the share of tax revenues on goods and services has increased;

fourthly, with each reform of the tax system of Kazakhstan, in the first year, tax revenue to the budget is reduced;

- fifthly, despite the reduction in tax revenues in the first year, in other years, tax revenues to the state budget increase significantly.

Comparing the previously presented hypothesis and the research results, we can confirm that as a result of the influence of international tax competition in Kazakhstan, tax revenues to the budget are reduced. But subsequent years, tax revenues increase in comparison with the prevailing income results. Based on this, the hypothesis is not fully confirmed.

Based on the results, one can make the following recommendation: according to comparison of VAT tax rates in Kazakhstan and Asia, in order to attract many taxpayers, Kazakhstan could reduce the VAT rate. Because in the past two years, the VAT rate in Asia has been lower than the VAT rate in Kazakhstan.

The results of reduction in tax rates and the provision of tax benefits in Kazakhstan brings a good stable result in terms of tax revenues to the budget, due to the fact that the tax base is increasing.

Today, Kazakhstan needs to maintain the momentum in reforming the tax system, in the direction of reducing the tax burden.

Thus, comparing and analyzing the advantages and disadvantages in the tax system and tax policy of Kazakhstan, we can conclude that the improvement of the taxation conditions, tax legislation in the country compared to other countries are more or less consistent with the requirements of the international market and taxpayers.

\section{References}

1. Smith A., An Inquiry into the Nature and Causes of the Wealth of Nations, 375 (Chicago, University of Chicago Press, 1976).

2. Gerasimenko N. V., Modern competition, 3, 11 (2007)

3. European Commission, Towards tax co-ordination in the European Union: a package to tackle harmful tax competition (1997)

4. OECD, Harmful Tax Competition: An Emerging Global Issue, https://www.oecdilibrary.org/taxation/harmful-tax-competition_9789264162945-en

5. Voronov A., Marketing, 5(60), 16-17 (2001) 
6. Wilson J. D., Wildasin D., Capital Tax Competition: Bane or Boon, Journal of Public Economics, 88, 1065 (2004)

7. Dietsch P., Oxford Publishers, 9-20 (2015)

8. KPMG's individual income tax rates table, https://home.kpmg/xx/en/home/services/tax/tax-tools-and-resources/tax-ratesonline/individual-income-tax-rates-table.html

9. KPMG's income tax rates table, https://home.kpmg/xx/en/home/services/tax/tax-tools-and-resources/tax-ratesonline/corporate-tax-rates-table.html

10. PwC and the World Bank Group, Paying Taxes 2019 report, https://www.pwc.com

11. World Economic Forum, Global Competitiveness Report 2018, http://reports.weforum.org/global-competitiveness-report-2018/

12. Code of the Republic of Kazakhstan "On taxes and other obligatory payments to the budget" (Tax Code), https://online.zakon.kz/document/?doc_id=36148637

13. Utibaev B.S., State budget, 50 (Economics, Almaty, 2016)

14. The World Bank, Data, https://data.worldbank.org

15. Arystanbekov K., Strategy and tactics of economic reforms, 29 (Sayasat, Almaty, 2017)

16. Matveeva T.Y., Introduction to Macroeconomics: Textbook, 411 (Allowance, Publishing, House of the Higher School of Economics, 2007).

17. Organization For Economic Co-Operation and Development, OECD Stat, https://stats.oecd.org

18. Nurumov A.A., Bekbolsynova A.S., KazUEFMT, 76-77 (2018)

19. Ziyadin, S., Streltsova, E., et al. (2019). Assessment of Investment Attractiveness of Projects on the Basis of Environmental Factors. Sustainability, 11(9), 2544. 